\title{
七二○一書投誌雜會究研 事醫堂天順
}

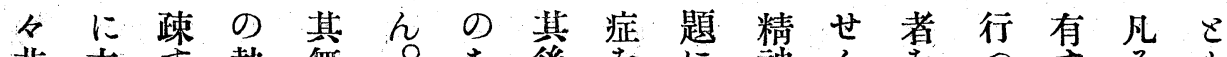
非本 守 執 無 ○

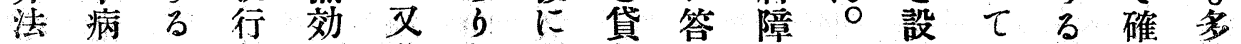

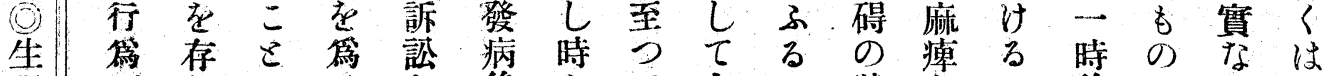

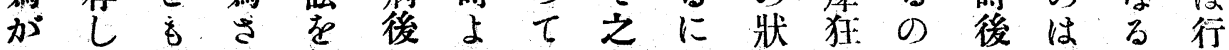

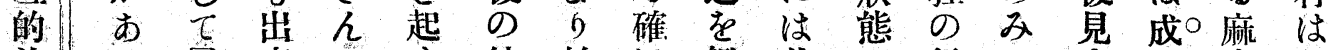

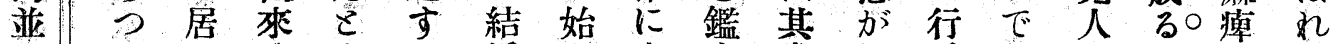

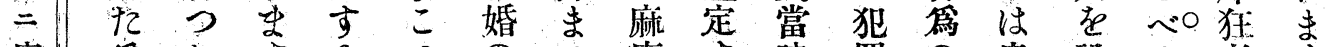

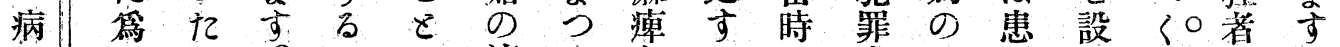

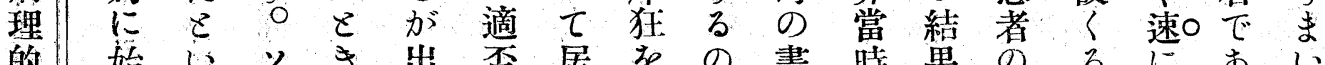

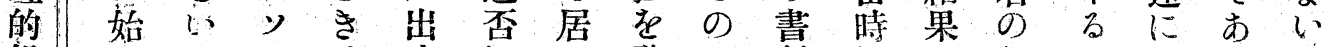

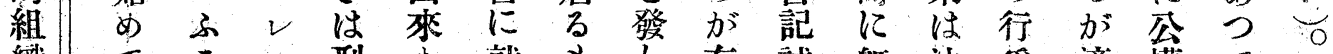

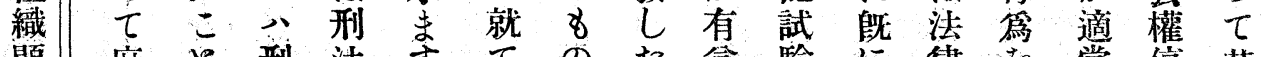
顯 麻 $を$ 刑法高て のた谷驗に律を當停其

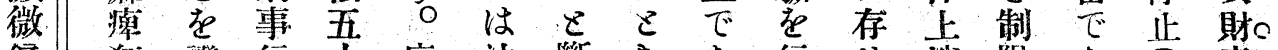
狂證行干魔法斷き市行世沙限

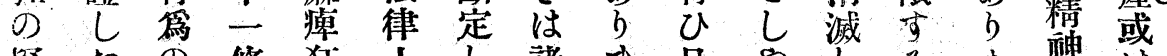

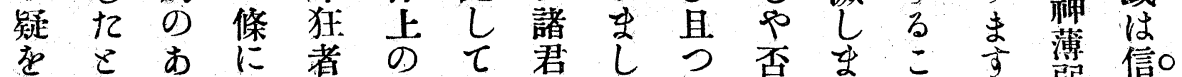

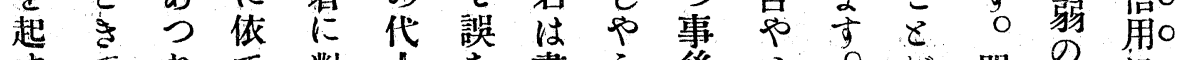

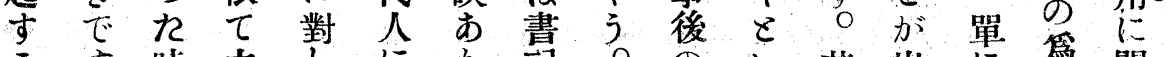

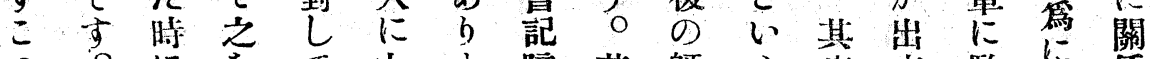

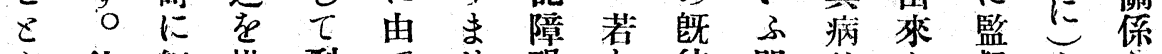

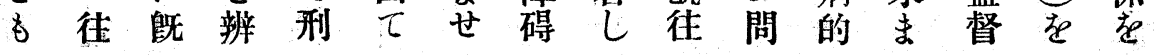

\begin{tabular}{|c|c|c|c|c|c|c|c|c|c|c|c|c|c|c|c|c|}
\hline 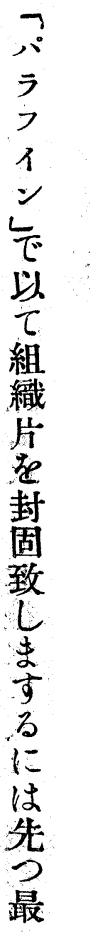 & 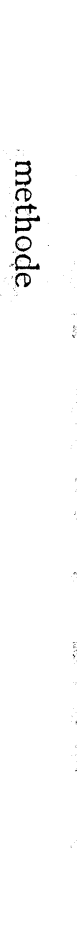 & 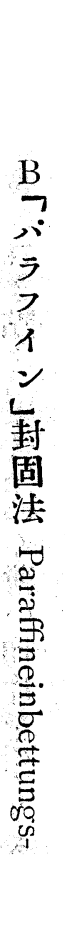 & $\begin{array}{l}\text { 菊 } \\
\text { 田 } \\
\text { 吉 } \\
\frac{\text { 吉 }}{\text { 郎 }}\end{array}$ & $\begin{array}{l}\text { 檢 } \\
\text { 查 } \\
\text { ⿹ } \\
\text { 指 } \\
\text { 針 } \\
\text { 承 } \\
\text { 前 }\end{array}$ & $\begin{array}{l}\text { @ } \\
\text { 生 } \\
\text { 理 } \\
\text { 的 } \\
\text { 蓝 } \\
\text { 病 } \\
\text { 理 } \\
\text { 的 } \\
\text { 組 } \\
\text { 織 } \\
\text { 顯 } \\
\text { 微 } \\
\text { 鏡 }\end{array}$ & $\frac{8}{8}$ & 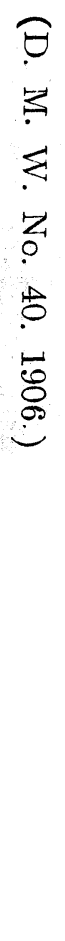 & 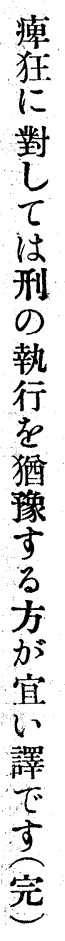 & 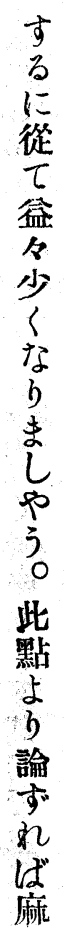 & 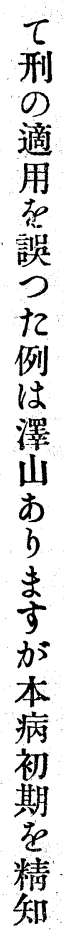 & 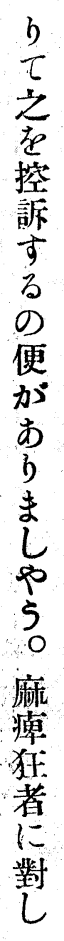 & 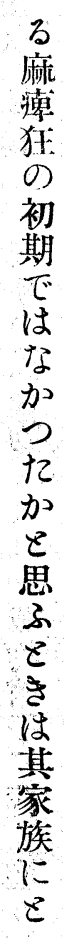 & 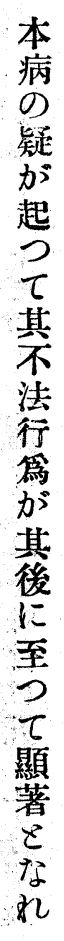 & 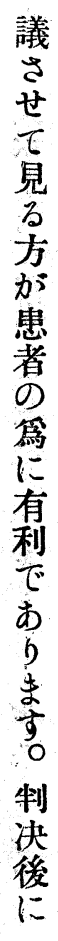 & 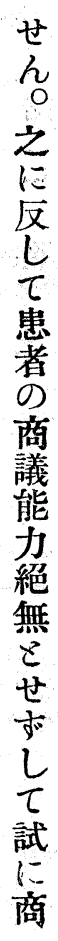 & 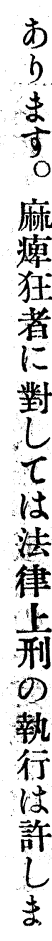 \\
\hline
\end{tabular}


號八百四第誌維會究研事醫堂天順 八二 0

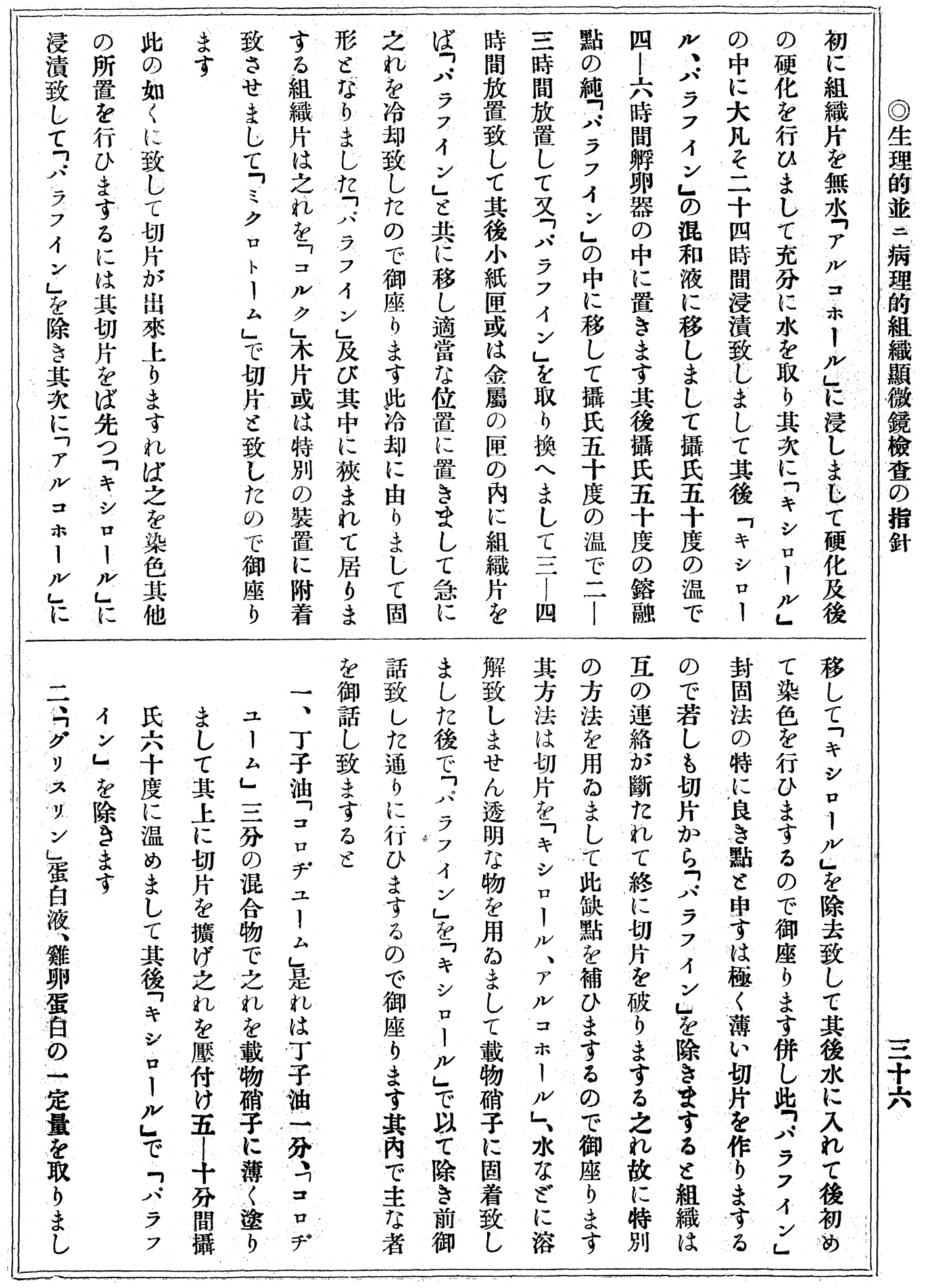




\section{九二○一書投誌雜會究研事醫堂天順}

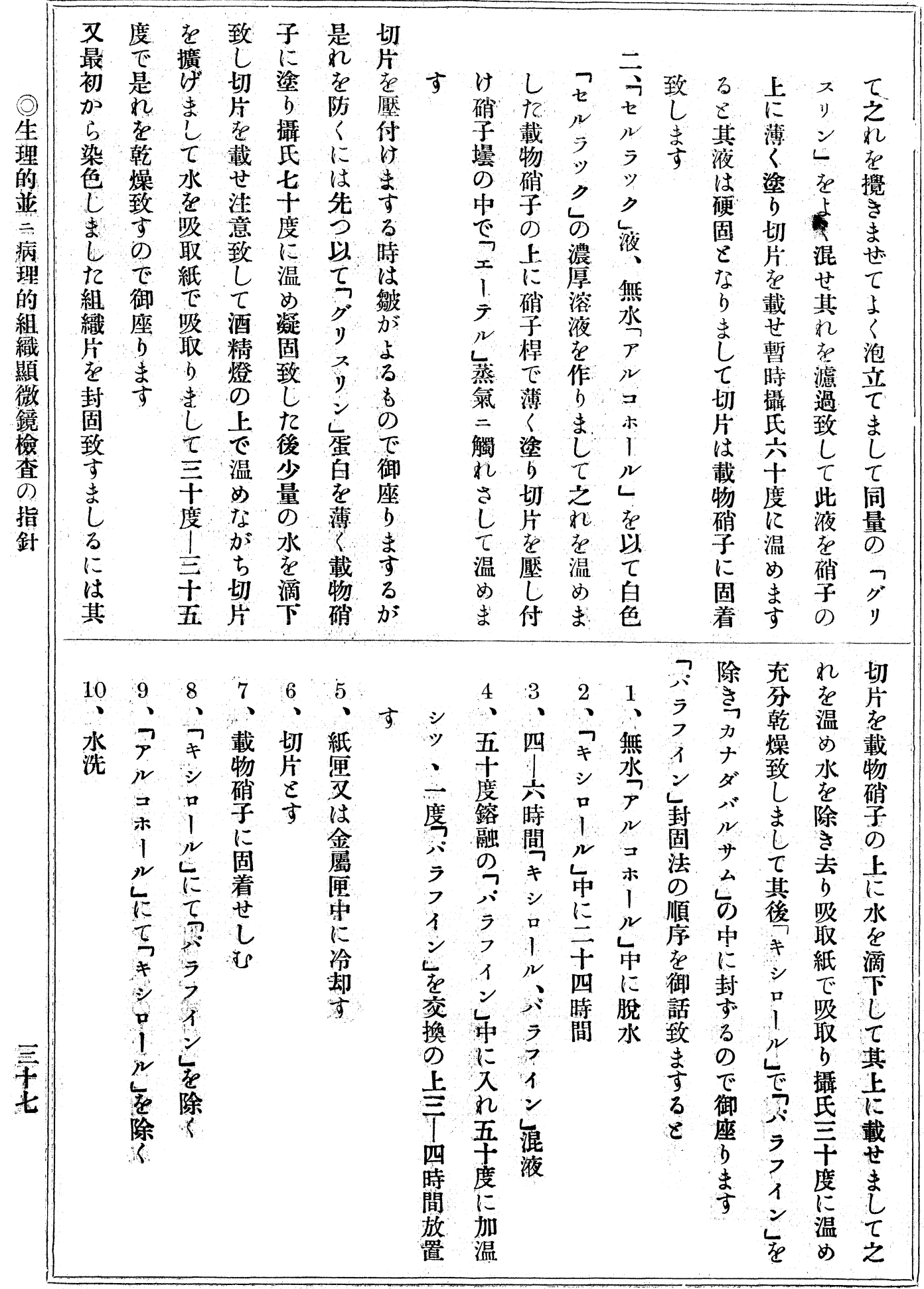


號入百四第誌権會究研事醫堂天順 $0 \equiv 0$ -

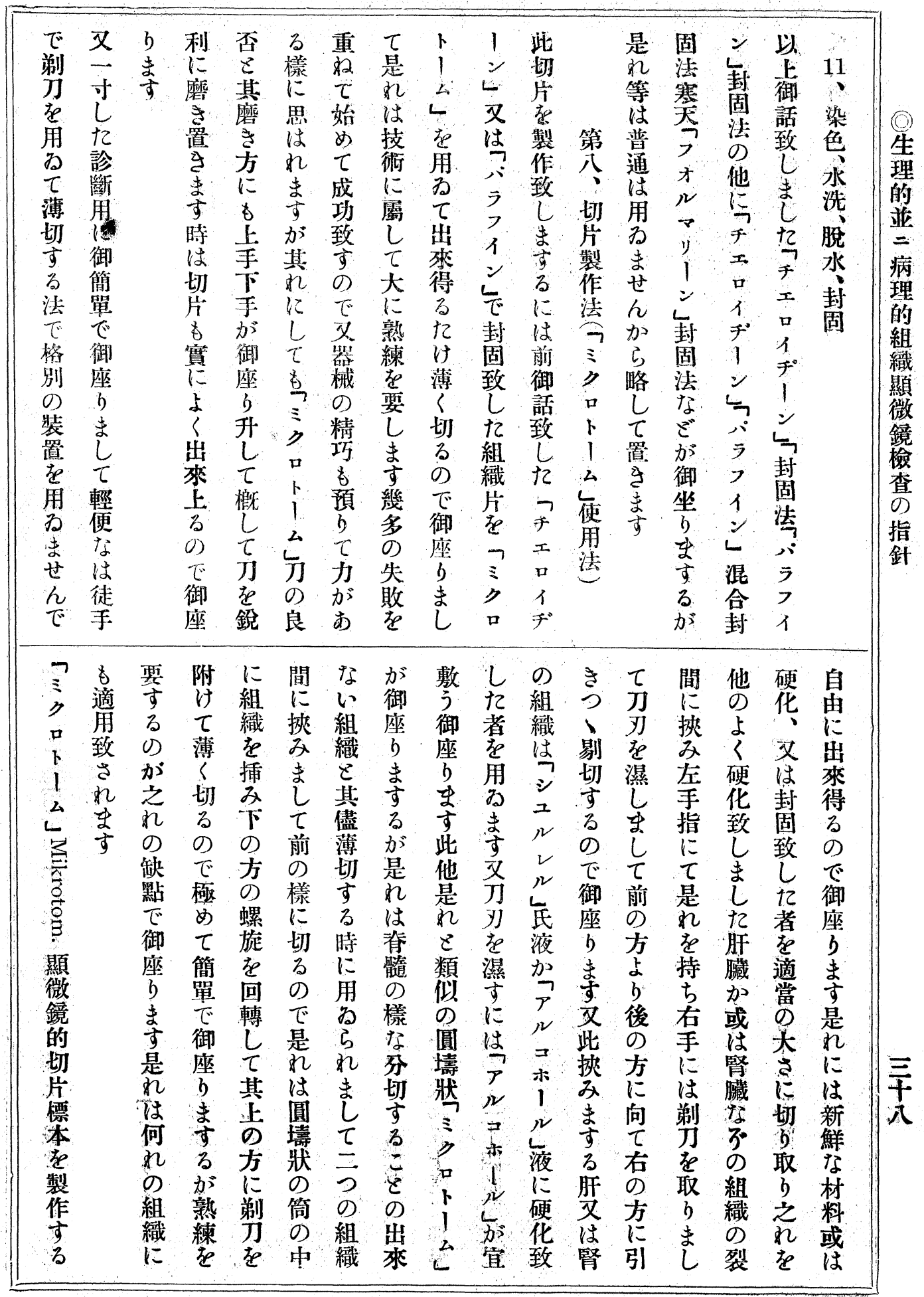


一三○一書投誌雜會觉研事醫堂天順

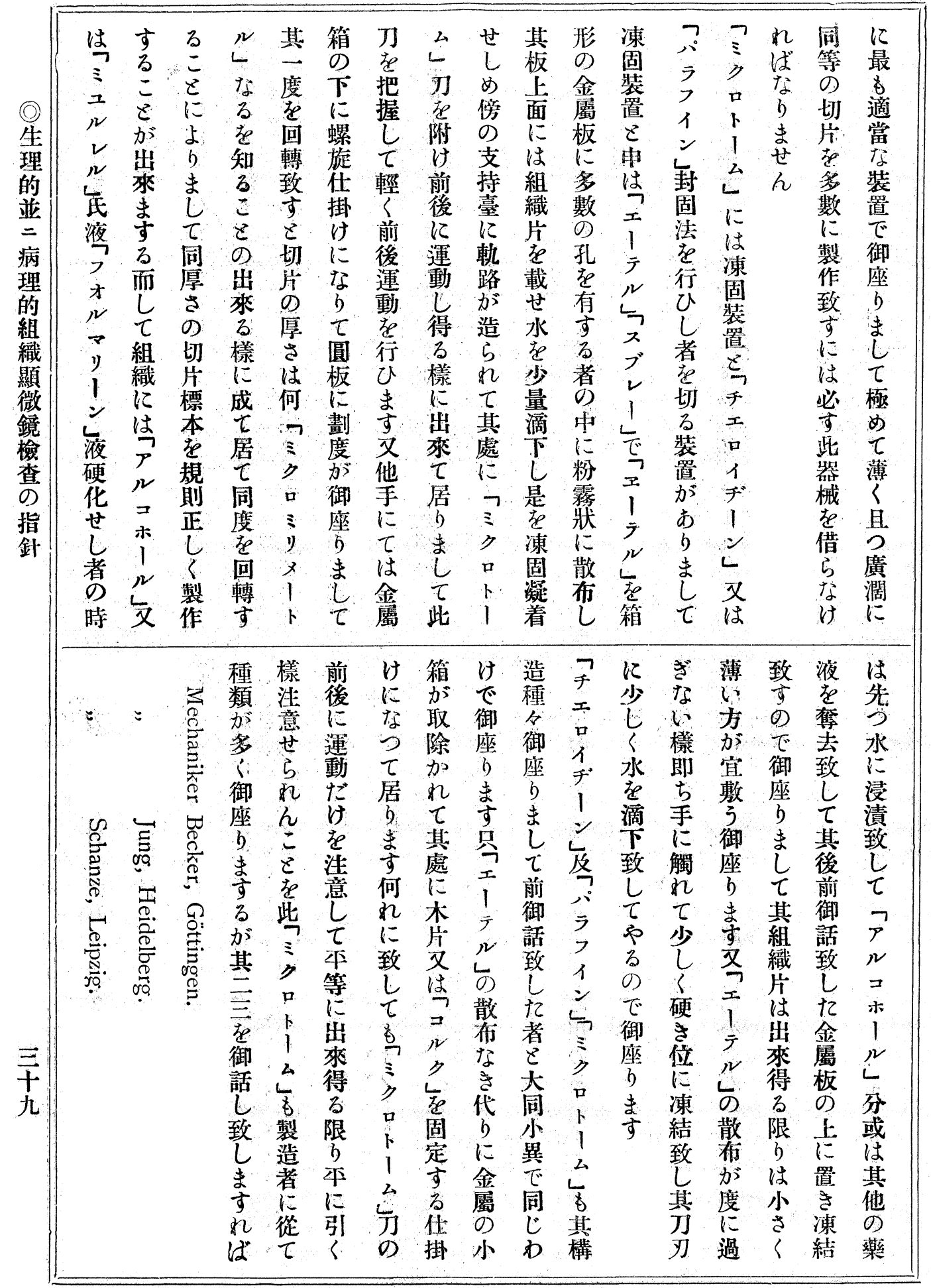




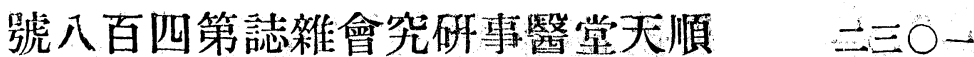

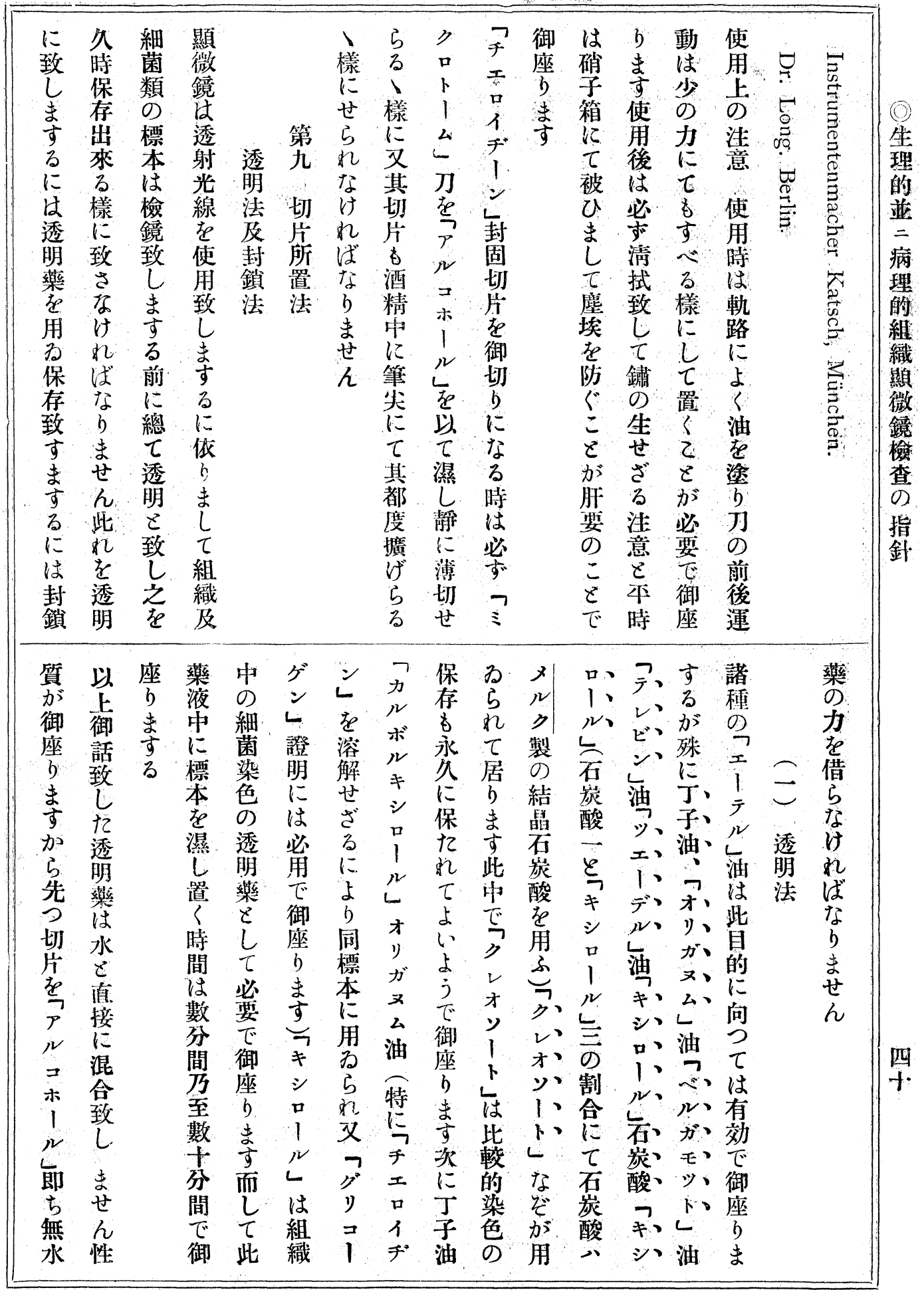


三三○一 書投誌雚會究研事醫堂天順

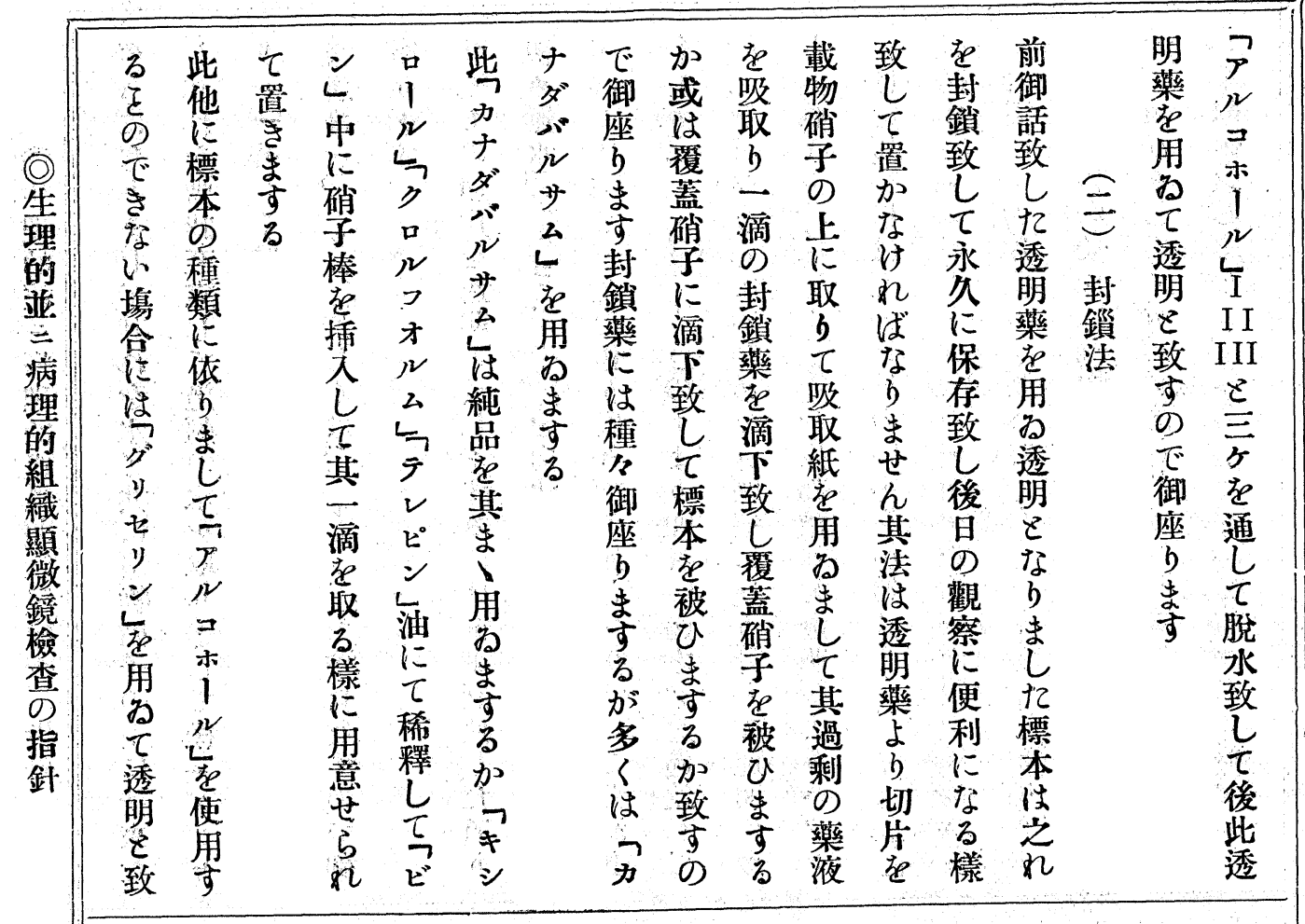

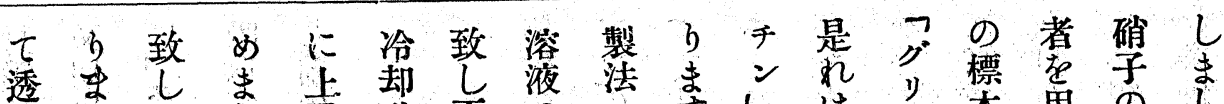

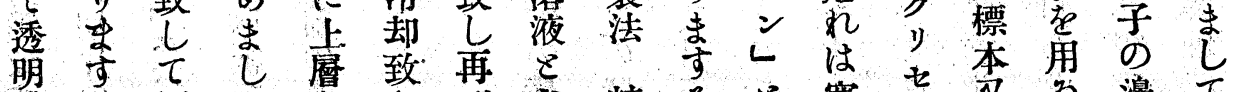

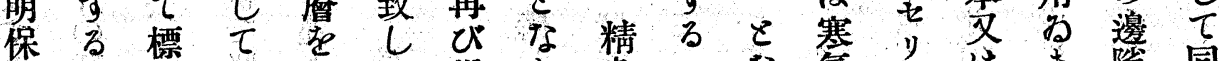

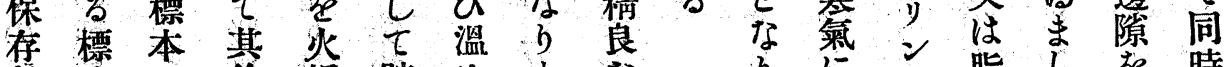

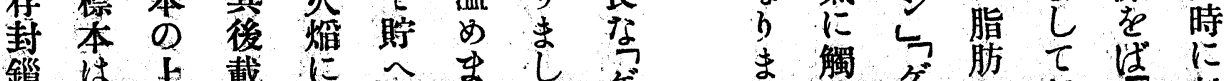

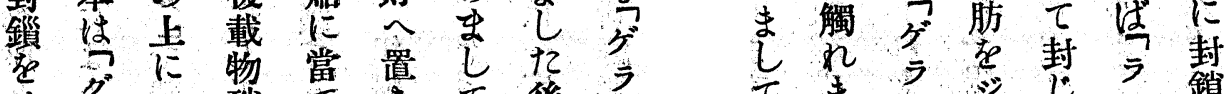

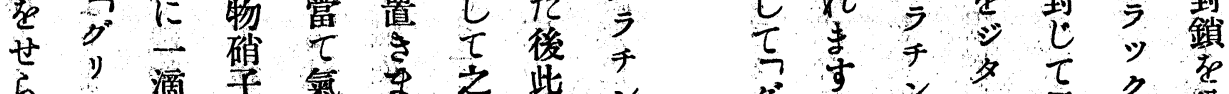

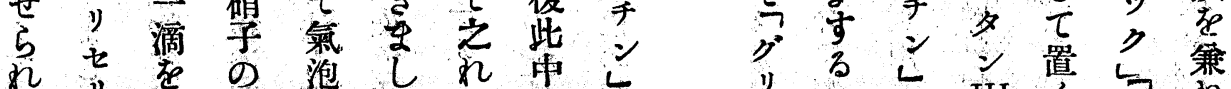

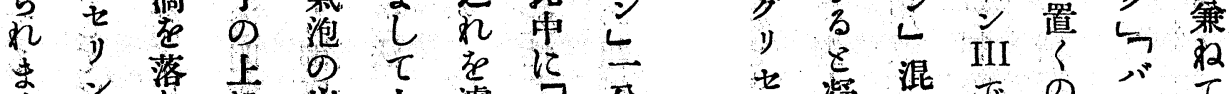

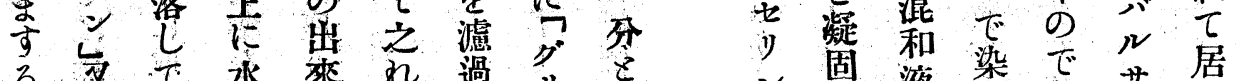

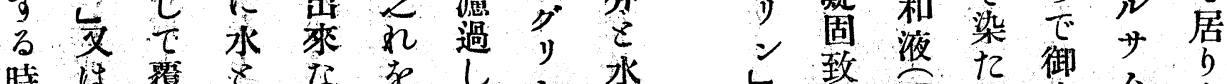

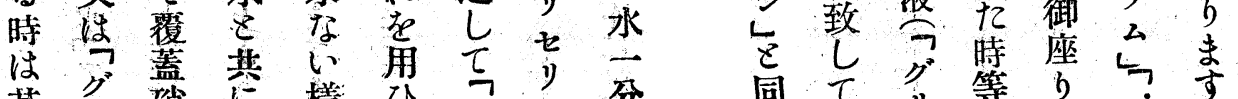

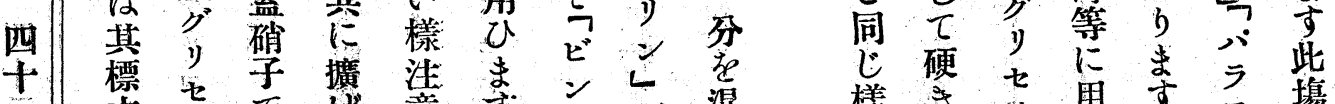

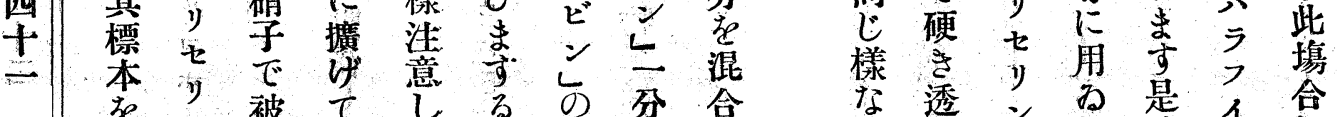

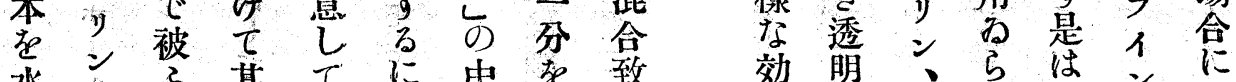

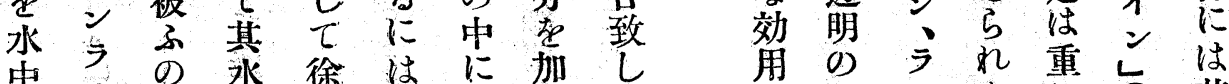

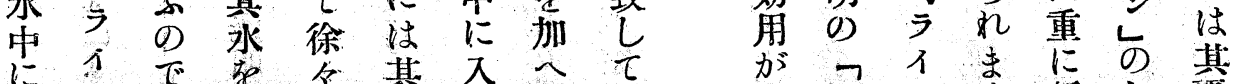

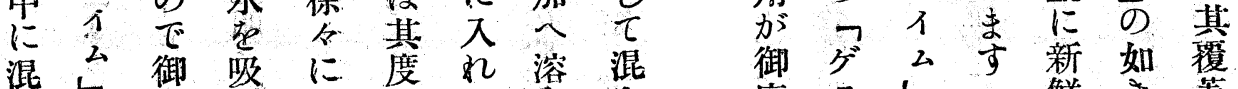

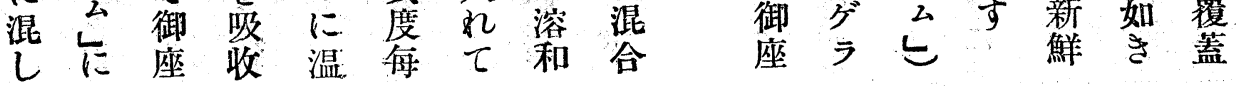


號入百四第誌雜會究研事醫堂天順四三0一

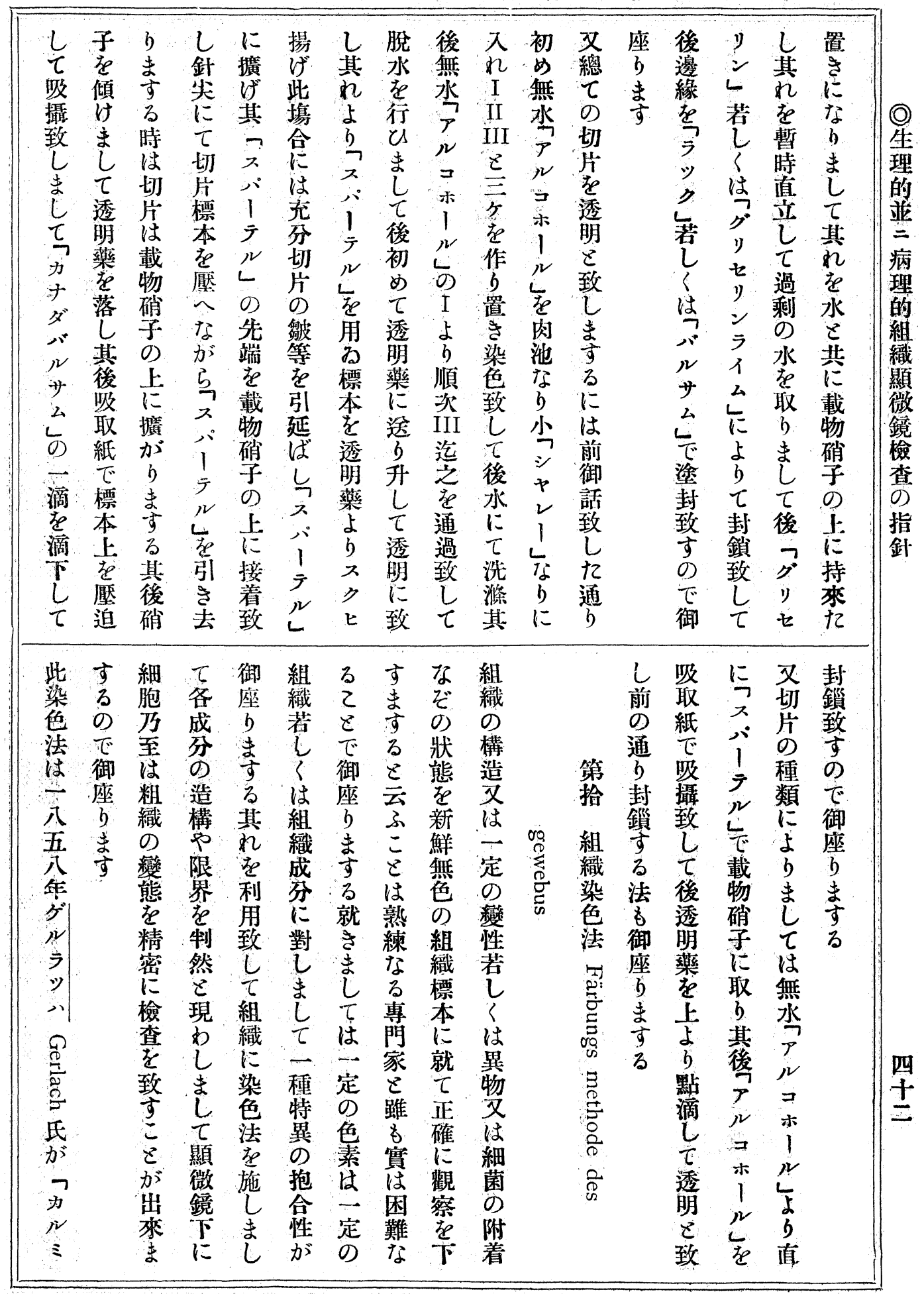




\section{五三0一書投誌雜會觉研事䣽堂天順}

\begin{tabular}{|c|c|c|c|c|c|c|c|c|c|c|c|c|c|c|c|}
\hline 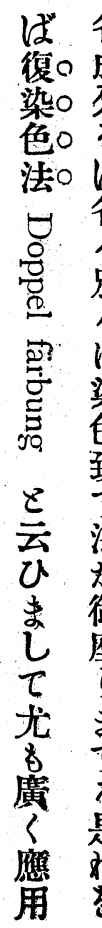 & 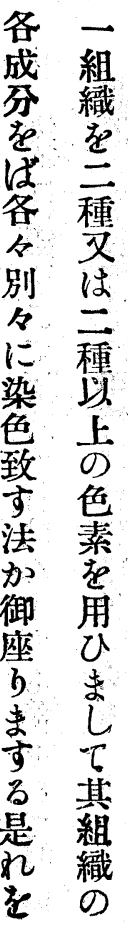 & 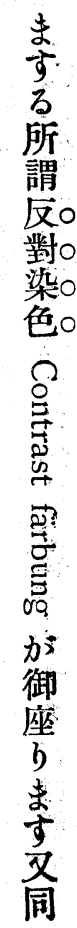 & 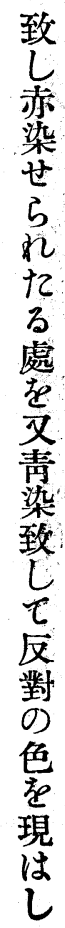 & 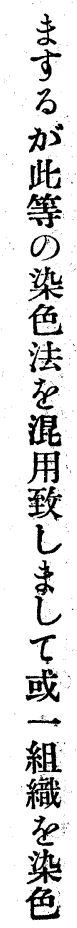 & 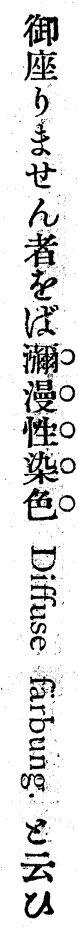 & 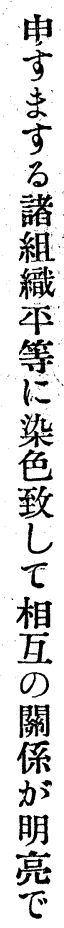 & 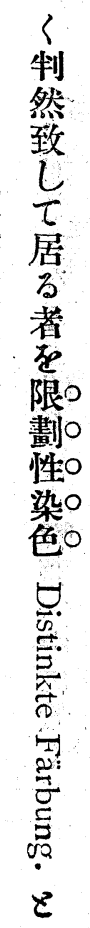 & 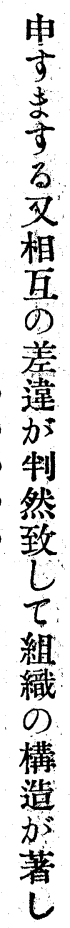 & 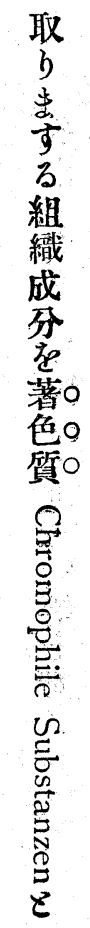 & 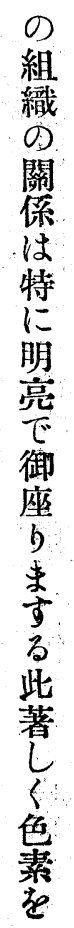 & 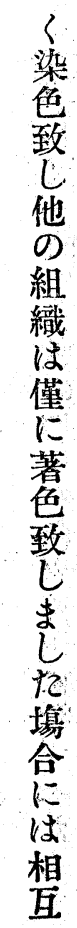 & 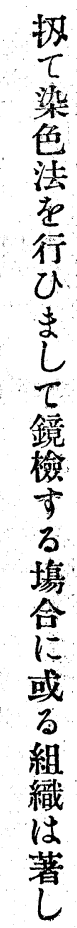 & 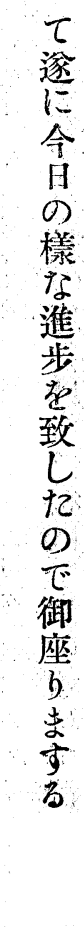 & 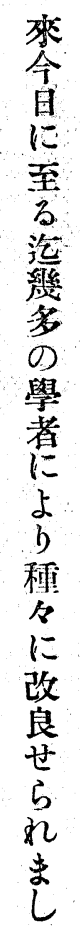 & 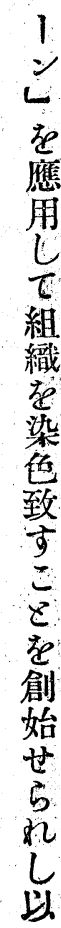 \\
\hline 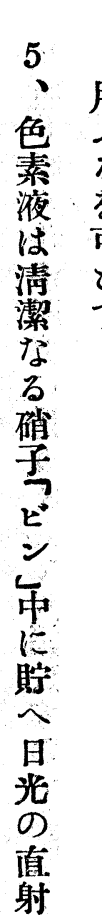 & 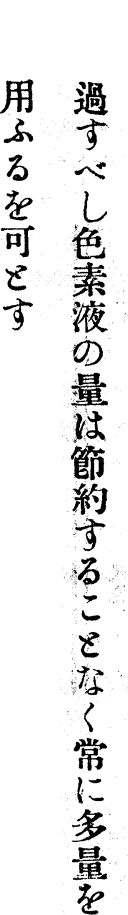 & 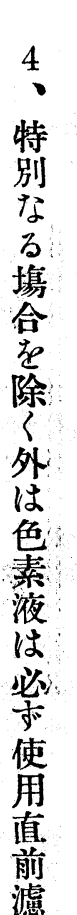 & 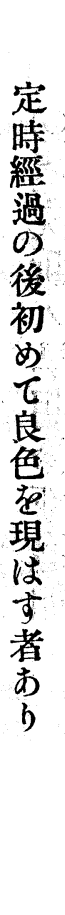 & 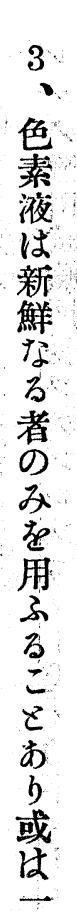 & 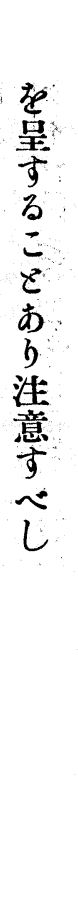 & 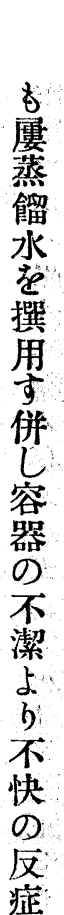 & 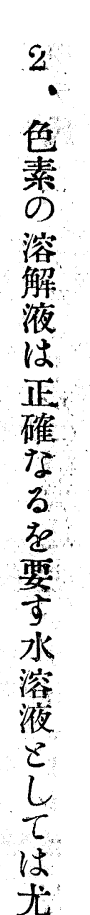 & 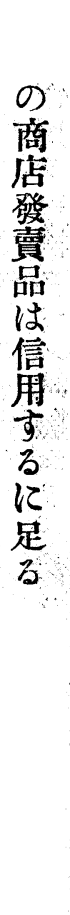 & 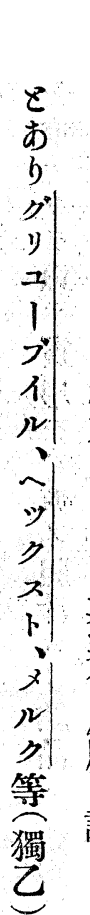 & 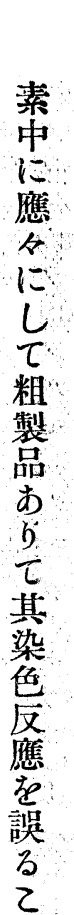 & 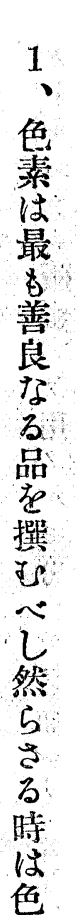 & $\begin{array}{l}\text { - } \\
\text { 般 } \\
\text { 染 } \\
\text { 色 } \\
\text { 法 } \\
\text { 通 } \\
\text { 則 }\end{array}$ & 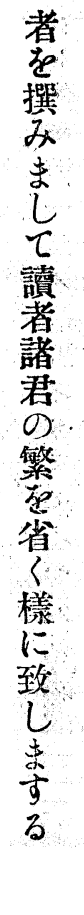 & 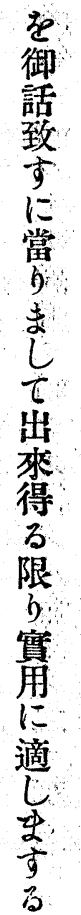 & 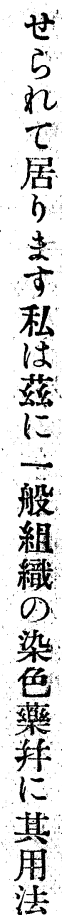 \\
\hline
\end{tabular}




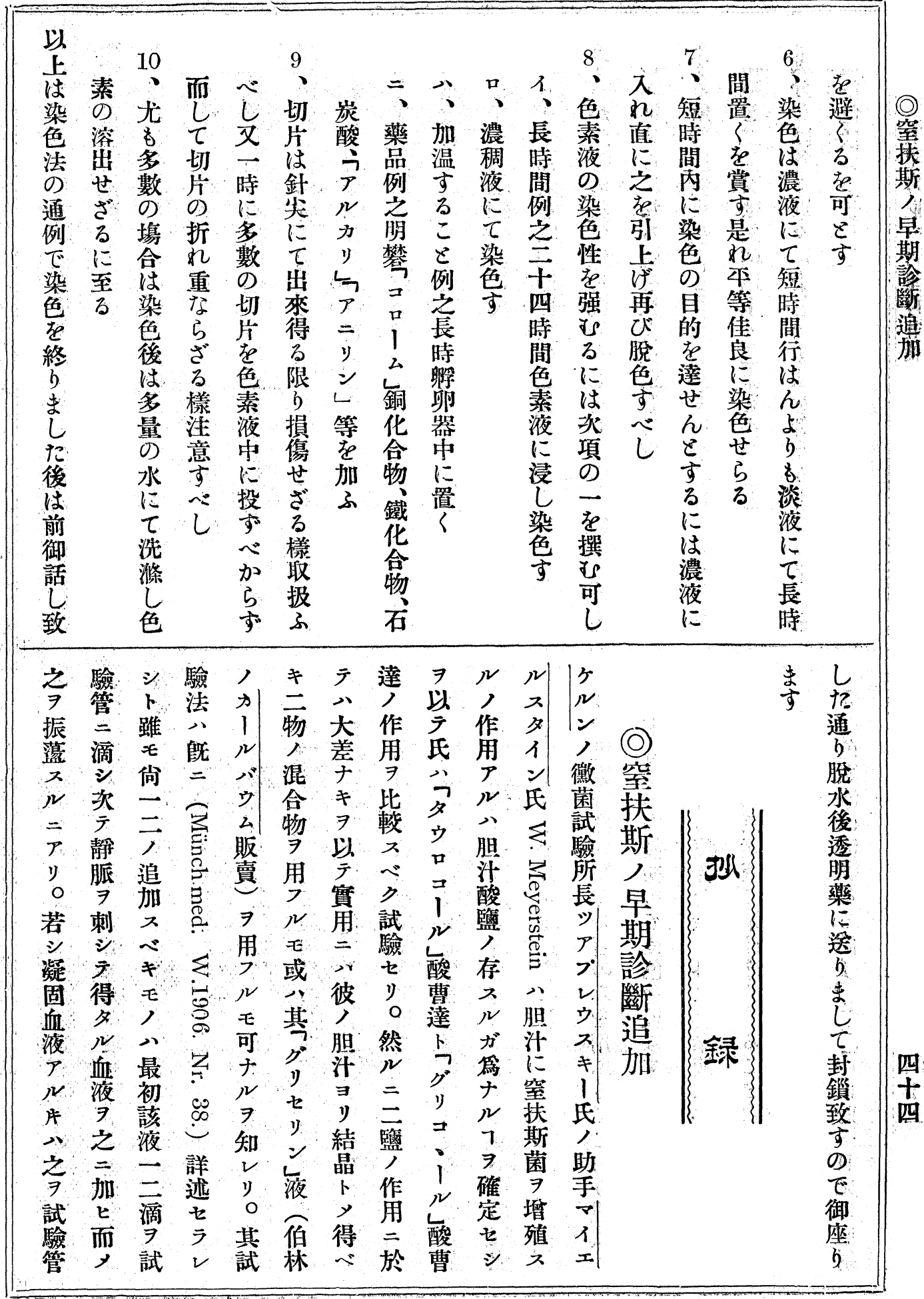

